Klára Brožovičová

ORCID: https://orcid.org/0000-0001-5486-0055

Instytut Etnologii i Antropologii Kulturowej

Wydział Etnologii i Nauk o Edukacji

Uniwersytet Śląski / Cieszyn

\title{
Changing cityscapes and the process of contemporary gentrification: The study of the transformation of a socially excluded area in Brno, the Czech Republic
}

\section{Proměny městských scenérií a proces současné gentrifikace: Studie proměny vyloučené lokality v Brně, České republice}

\begin{abstract}
The main goal of the paper is to report and explain the ongoing process of gentrification in an excluded area Bratislavská Street - Cejl Street in Brno, the Czech Republic. It is a specific study describing the process of gentrification in general on the basis of a specific case. The findings of this study come out of a long-term field survey in the form of regular visits to that area of Brno, carried out from 2008 to 2012. Since 2012 the research has been carried out in form of observation of the area's environment and the author's stay in that area. The research and following analysis are based on the "actor-centred approach".
\end{abstract}

Key words: social exclusion, gentrification, Brno, the Romani, integration, NGO, actor-centered approach

Hlavním cílem př́spěvku je objasnit a vysvětlit probíhající proces gentrifikace ve vyloučené oblasti ulic Bratislavská - Cejl v Brně. Jedná se o specifickou studii popisující obecně proces gentrifikace na základě konkrétního př́padu. Závěry této studie vycházejí z dlouhodobého terénního průzkumu provedeného v letech 2008 až 2012 formou pravidelných návštěv této oblasti Brna. Od roku 2012 je výzkum prováděn formou zúčastněného pozorování lokality a dlouhodobého pobytu autorky v této oblasti. Výzkum a následná analýza jsou založeny na „př́stupu zaměřeného na aktéra“.

Słowa kluczowe: sociální vyloučení, gentrifikace, Brno, Romové, integrace, nevládní organizace, př́istup zaměřený na aktéra 
The goal of this article is to describe and explain the process of gentrification in an excluded area Bratislavská Street - Cejl Street in Brno, the Czech Republic. It is a specific study describing the process of gentrification in general on the basis of a specific case. The findings of this study come out of a long term field survey carried out from 2008 to 2012 in forms of regular visits to that area of Brno. Since 2012 the research has been carried out in form of observation of the area's environment and the author's stay in that area. Apart from documentation and observation, in depth interviews were made, and several hours of recordings with the residents, officials and the workers of non-profit institutions were collected. The total number of respondents is 35 and it comprises all mentioned under-researched groups, i.e. existing residents, newcomers, non-profit organisations workers and the city officials. To be more precise, the size of the sample in individual groups depended on the availability of respondents and total size of each group. The groups of professionals contained both together 10 respondents ( 5 non-profit organisation workers - each from the different non-profit organisation, and 5 city officials). The group of newcomers was represented by 12 interviewees, group of existing residents by 13 respondents taking into account social economic status, ethnicity and marital status. The respondents have been visited repeatedly in in the last mentioned two groups during the research. The interviews have been transcribed and detailed qualitative analysis was performed (Atlas.ti).

The research and following analysis are based on an "actor centred approach". The activities and interests of the gentrification process' participants are studied, and their attitudes and activities are identified through their responses. The participants were divided, on the basis of preferred interests, into four groups: 1) existing residents (most of whom are Roma and socially weak people 2) a newcomer, so called gentrifies 3) non-profit organisations workers 4) the city officials.

While analysing gentrification process in the city part Bratislavská Street - Cejl Street the question whether the ongoing gentrification leaves any room for integration of the existing residents arises.

In the following paragraphs of this article there are references to the history of the Brno city and the city part Bratislavská - Cejl, with the modern history being described in detail.

Theoretical basis of the research and explanation of the analytical framework of the project follow. The core parts of this article are sections in which the author explains the strategies of individual groups of people studied, and furthermore presents the outcomes of the field research. The summary of individual strategies of groups of people as well as of individuals presented at the end of this article portrays the current situation in the area.

\section{The history and brief characteristic of the Brno}

Brno is the second biggest city in the Czech Republic. According to the 2011 census, it is a home to more than 386000 people. ${ }^{1}$ Brno is an important administrative

1 SLDB 2011 - vybrané výsledky podle městských částí Brna. 2011. Český statistický úřad, 12.03.2019. 
centre, mostly of the South Moravia shire. It is a home to the Supreme Court, the institutional court, the office of the ombudsman. It plays an important role in education, as there are many universities in Brno with it being the Masaryk University, VUT, Mendel University in Brno, Veterinary and Pharmaceutical University, Janáček Academy of Arts. Brno has recently become a home to young professionals working in new materials research and development, namely in Central European Institute of Technology, IBM, AVG Technologies, Red Hat, Honeywell etc.

Brno was historical and industrial centre of the former Austrian-Hungarian monarchy and later of Czechoslovakia. It became famous mostly for its textile industry. Factories for Wool cloth production were built from the end of the 18th century, and in the beginning of the 19th century Brno was called the Moravian Manchester. This reputation vanished with the beginning of the WW2 when the owners of the factories, most of whom were of Jewish or German origin, had their factories taken. With the onset of the communist regime in Czechoslovakia in 1948, the textile factories were united under state owned companies called Mosilana and Vlněna. The textile factories as well as the homes for its workers were located in the area of Cejl, Kolišter, Křenová, Špitálka and Bubeníčkova streets, which in fact nowadays form excluded areas. Arms industry developed in the 20th century. The company Czechoslovakian arms factory founded in 1918 produced, apart from weapons, cars engines and tractors (Zetor Z-25).

As aforementioned, Brno was a multinational city before the WW2. Most of the Jewish people were deported during the WW2 ${ }^{2}$ In the time just after the WW2 ended, on the 31st May 1945, people of German origin, around 27000 people, were expatriated. As a consequence of these forceful events and due to the state borders being closed after the onset of the communist rule, Brno became more or less ethnically homogenous ${ }^{3}$ The only exception was a few minorities and the Roma, who were forced to assimilate. There were some changes to the ethnical model in Brno after 1989. Among the new ethnical minorities that emerged after 1989 , the Vietnamese minority is to be mentioned, as well as numerous Slovak minority, Polish and Russian minorities. ${ }^{4}$

\section{The development of the excluded areas over the past $\mathbf{2 5}$ years}

As aforementioned, the excluded area in the vicinity of the city centre is located in the place of former textile factories. The area got inhabited by Brno citizens after the WW2. The former workers' flats became out of date over the time and did no longer live up to quality living standards. As the state of the buildings and flats got worse, the flats were occupied by socially weak people and the Roma. Some of the Roma had already been living there for some time as they were former workers of the textile factories.

2 Official website of the Institut Terezínské iniciativy, 19.03.2019.

3 Pospíšilová, Brožovičová 2015, pp. 157-177.

4 Pospíśilová, Poláková, Brožovičová 2015,pp. 18-34. 

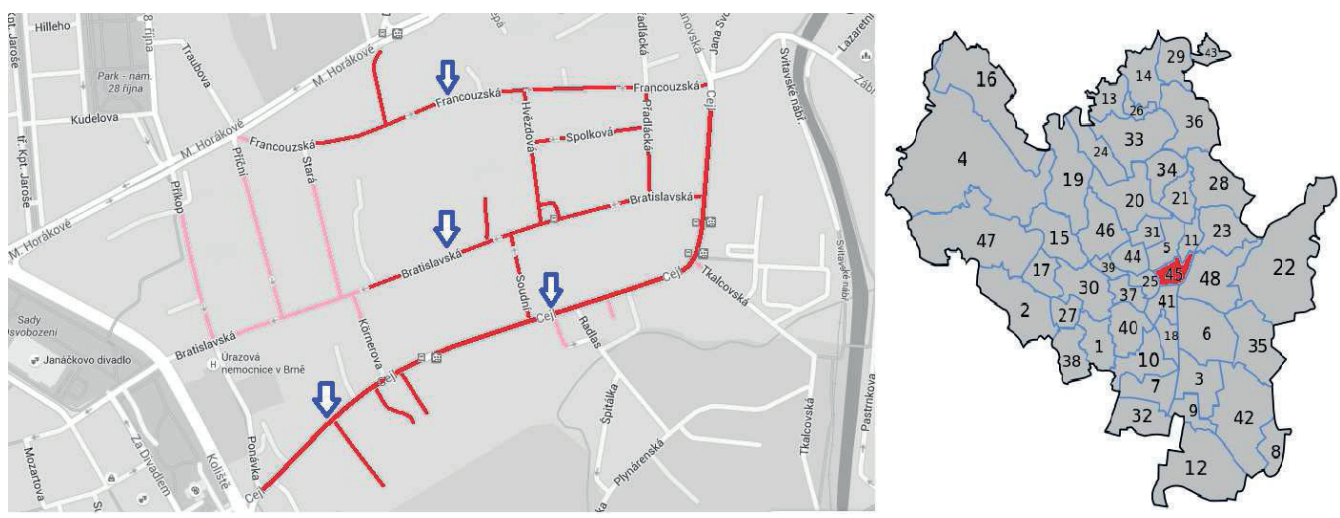

The specificity of the area is that the city centre is very close (shown in the map as no. 45). The area itself is defined by a few main streets, as indicated in the map by arrows, with it being Cejl Street and parallel streets Bratislavská and Francouzská. Perpendicular to these are Körnerova, Soudní, Př́ční, Stará, Hvězdová and Přadlácká streets. Streets adjacent to this area are highlighted in the map, where already gentrified streets are coloured in pink, and streets with gentrification in progress are coloured in red.

This area had, in the nineties, strong characteristics of an excluded area, such as: houses in bad or ruined condition, high percentage of socially weak Roma, public areas in bad condition, high crime level, high concentration of gaming clubs and pawnshops. A that time the Brno citizens nicknamed it the Brno Bronx. First investments were made in the nineties too. The IBC administrative centre built in 1997 standing at the edge of the excluded area is to be mentioned. As far as cultural institutions are concerned, the puppet theatre Radost, which is close to the centre of the excluded area, was reconstructed in 1999. The museum of Roma culture was founded and built in the centre of the area in 2000. These pilot projects can be seen as the first steps leading to the current changes being in progress in the area.

If we focus on the projects to improve the standards of living in the area, the community housing project carried out by a non-profit organisation DROM in 1999-2003 is to be mentioned. Two ruined houses were reconstructed as a part of the project.

The reconstruction works were done mainly by indebted Roma tenants, who had been living there by then. They were offered a 1 year tenant contract, and their debts were taken as paid after they had worked certain amount of working hours and had shown adequate participation. The DROM organisation provided the Roma with social housing under adequate terms, and furthermore helped improve the then status quo in the area.

After the year 2000 the students of Brno colleges began to live in the area on regular basis. The rented flats are often shared by $4-6$ students. 
Students usually seek low living costs, and this area is, in these terms, attractive for them. Students are usually less conservative and are more open to accept socially and ethnically diverse neighbourhood.

After 2007 there was an increase in the number of flats privatized in the area as well as increase in the numbers of newcomers buying starter flats. Professional real estate speculators began to simultaneously purchase flats in this area.

These changes took place following the Integrated plan of the Brno city development, which was supported by the European union, when massive reconstructions of apartment houses was set off. However slow it was in the beginning, gentrification accelerated significantly after 2007.

\section{Conceptual framework of gentrification and factors of inclusion and exclusion}

The concepts of inclusion, exclusion and gentrification were taken into account during the research. Gentrification as a social phenomenon was described by Ruth Glass on the example of London. She presents gentrification as a process when ruined, shabby, small houses or flats in former working class parts of the city are occupied by members of the middle class, and concurrently rapid development of infrastructure and facilities follow. ${ }^{5}$ While Glass points out economic aspects in her definition of gentrification, in which she suggests that one of the main characteristics is physical recovery of the area based on changes in ownership, Neil Smith, on the contrary, came up with a definition at the end of 1970s based on economic principles.

Gentrification, as defined by Smith, is forced by influx of private capital in the area of inner city inhabited formerly by workers, with the middle class members moving in the area being the investors. ${ }^{6}$ Smith sees cheap resources offer as an impetus to gentrification while the main impetus to gentrification is so called rent gap, ${ }^{7}$ with that being gap between current levels of rents charged and the actual value of real estates. As opposed to purely economic explanation of gentrification, David Ley suggests that the middle class member are motivated to move in these areas on the basis of these being located close to the city centre and on the basis of the character of the site, as well as on the basis of the architecture issues and overall distinction between these areas and homogenous environment of the city. ${ }^{8}$

Crucial is the theory of Chris Hamnett joining both aspects of gentrification, economic and social, in which gentrification is defined as spatial manifestation of the society shift from industrial to post-industrial economy, taking into account projection of this economy in the structure of the citizens, as well as jobs structure and real estate's market. ${ }^{9}$

\footnotetext{
5 Glass 1964, p. 342.

6 Smith1996.

7 Smith 2003, pp. $462-465$.

8 Ley1986, pp. $521-535$.

${ }^{9}$ Hamnett 2003, pp. $2401-2426$.
} 
The theories on integration have been framed by the paradigms of identity and social change..$^{10}$ According to John Ogbu the concept of integration is based on the relation between the minority and the majority and its influence on potential integration or on possible integration dismissal. John Ogbu describes ethnical minorities in the context of the United States of America and divides them into two groups. The former are the voluntary minorities, the latter are involuntary minorities. Ogbu regards voluntary minorities such groups of people whose members who joined the majority out of their own free will and concurrently they see perspective in the majority. The members of the involuntary minority were, on the contrary, born to a minority that had been pushed by the majority to the edge of society, and so their social status does not reflect their will. On the basis of this fact Ogbu derives identity influenced attitudes which are based on people belonging to a social group either voluntarily or involuntarily. On the grounds of the identity being voluntary or involuntary the social distance of a minority emerges as well as possible integration or integration dismissal. ${ }^{11}$

John Ogbu works with the identity of an immigrant or a member of an ethnic minority that stems from voluntary or involuntary membership, which in turn influences the attitudes towards the majority and the will to integrate. The concept based on identity of an individual was further developed by Klaus Zimmermann and Amelie Constant, who focus mainly on integration that reflects mainly in economy. Zimmermann and Constant ${ }^{12}$ suggest socio-economical explanation of migrants integration as well as ethnical minorities integration. They link the rate of integration of an individual in the majority with the probability of succeeding in the job market.

In the postmodern society the economical production and participation in the job market, which is indispensable part of a social status, is among the major outer causes of exclusion. ${ }^{13}$ The participation in the job market has become such a crucial issue, that it enables or, alternatively, disables behaviour forced by consumption patterns, and is concurrently one of major sources of exclusion." ${ }^{14}$

Like Bauman, Townsend too emphasises material deprivation as the main cause for exclusion. Townsend argues that long term material deprivation prevents individuals from fully enjoying their citizen's rights; poverty is thus seen as an obstacle preventing from social participation.

Deprivation can occur due to insufficient income or directly through the basic needs not being sufficiently satisfied, without which people can not satisfy their social needs. ${ }^{15}$

\footnotetext{
${ }^{10}$ Finney, Simpson 2009.

${ }^{11}$ Ogbu 2003.

${ }^{12}$ Constant, Zimmermann 2011, pp. 145 - 168.

${ }^{13}$ Sirovátka 2007, pp. 85-99.

${ }^{14}$ Compare: Dahrendorf 1988.

15 Townsend 1979.
} 
Peter Marcuse set up a model based on prevailing economic causes, in accordance with which several segregation formations come to existence, e.g. ghettos, slums, citadels or ethnic enclaves. Marcuse bases the typology of spatial exclusion on segregation and social status.

Marcuse distincts two forms of exclusion on the basis of socio-cultural segregation, with that being the ghetto, the condition of which is involuntary exclusion of a group of people. Ethnic enclave, on the contrary, segregates itself from the majority fully knowingly. Marcuse distincts, on the basis of economic status, habitat forms of citadels, where people separate themselves in guarded city parts. ${ }^{16}$

Economic causes are not the sole factor leading to exclusion. Poverty is significant but by no way it is the most important dimension of social exclusion. Poverty is relative and varies significantly in global terms, and is bound with global socio-economic development. ${ }^{\text {17 }}$

Vleminckx and Berghman describe exclusion as a multidimensional event consisting of several processes of deprivation that are closely connected with complete dissociation from the former social group. This multidimensional process leads to the individuals being gradually isolated from the majority as well as from mainstream opportunities offered by the majority. ${ }^{18}$

Silver and Miller developed typology of processes leading to exclusion, defining:

Social exclusion 1) is multidimensional or socio-economic and includes individual resources as well as group resources, 2) dynamic or procedural following trajectory between full integration and a number of exclusions, 3) distance exclusion connected with social distance or isolation, rejection, humiliation, the lack of there being a social protection network, and refusal to participate.4) active exclusion, as it is always connected with behaviour which evidently leads to exclusion, 5) relative. Disregard, discrimination and humiliation are as present as poverty physical needs. Even a social state can exclude some of their citizens out of the protection of state or to make them imprisoned by unemployment. ${ }^{19}$

\section{Analytical Framework of the gentrification process}

While analysing the situation in the researched area, we chose the actor centred approach as a basis for the research. Four groups of participants can be identified in the process of gentrification in the aforementioned part of Brno, with that being: 1) the current residents (most of whom are socially weak people and the Roma), 2) gentrifies, 3) non-profit organizations, 4) the officials of the Brno city.

\footnotetext{
${ }^{16}$ Marcuse 1997, pp. 311-326.

${ }^{17}$ Bonner 2006.

${ }^{18}$ Vleminckx, Berghman 2001, pp. 27-46.

${ }^{19}$ Silver, Miller 2003, pp. 8-26.
} 


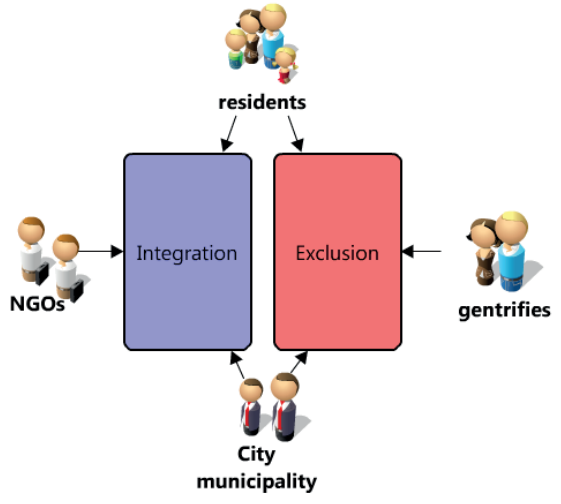

Each of these groups is defined by activities of their own and their own interests, by which they contribute to the integration processes or to exclusion of the current residents. That, in other words, means that they either participate in the gentrification process or act against it.

As shown in the chart, original residents and the Brno city administration concurrently contribute to the processes of integration and exclusion. The non-profit organisations activities are exclusively those of integration and ties are exclusively those of integration

help the current residents to integrate with the new social environment in the area

The newcomer, so called gentrifies, encourage, through their interests, exclusion of the current residents. The strategies and interests of individual groups will be described in the following sections of this article.

\section{The Strategies and goals of the current socially weak and Roma residents}

The strategies of the current residents can be seen as ambivalent; the current residents contribute through their activities to their exclusion and inclusion at the same time.

On behalf of integration, there is a strong urge of the current residents to stay in the area, often supported by local patriotism or sentiment to the area. A prime example of this feeling can be the statement of Barbora, current resident (2008). I'm used to being here, that's the way it is. I'm used to living here, I'd rather live here, rumour has it there's gonna be reconstructions. Mrs Barbora was born in the area and has been living in a flat with her parents ever since, her family has broadened by her husband and two children. The urge to stay in the area suggests the possibility of taking the first step to accepting homogenisation dynamics and accepting the middle class's life attitudes of the gentrifies.

The acceptation of changing social context in the area and expressing the will to stay is the first precondition for possible integration of the original residents with the newly forming social bonds in the area. ${ }^{20}$ In this respect, there is the possibility of equal participation in the integration process on both sides. ${ }^{21}$

The current residents are open to the possibility of there being a multiethnical neighbourhood and to new residents of the majority coming, which they unequivocally welcome as it as an important step to be taken towards changing the present situation.

\footnotetext{
${ }^{20}$ Maloutas 2011, pp. 33-48.

${ }^{21}$ Holzner 1967, pp. 51-62.
} 
The openness to the gentrifies coming and putting stress on the social homogeneity of the excluded houses being terminated are important in terms of integration of socially weak residents.

Two statements recorded incidentally at the beginning and at the end of the research are interesting. Field social worker Radka had this to say on the situation.

"As far as I know the Roma, they don't like the excluded areas here. They often say, well they like to live together as a family, want to have their relatives close, but when there are too many of Roma in one place, they say: It is not very good here, there are only Roma here and problems keep cumulating and that is bad". (Radka - non-profit organisation representative, field worker, 2013)

A similar idea shows the statement of Mr. Bohumil, who lived there in 2008:

It's a timed bomb putting the gypsies together. If you give them new flats, I can guarantee you that the flats will be ruined so much you won't be able to recognize the within five years. They will only mind their business unless if you put them together with normal people... well I have lived in Karlooy Vary in block of flats, and there never were any problems with them. (Bohumil - original resident, 2008)

Klaus Zimmermann assumes that the urge to step out of the excluded group is crucial for creating an identity matching the minority with the majority, and thus opening the way to socio-economic success. ${ }^{22}$

As a matter of fact, there are also strategies of the current residents supporting staying in the excluded group. These strategies stem from acceptance of specific behavioural pattern accepted within the excluded group, which is, nonetheless, not accepted by the majority, which in turn leads to the exclusion being more intense. The tendencies to become indebted, high unemployment rate and refusal to cope with the present problems were identified among the original residents during in depth interviews.

The high number of family members can also pose a problem, as they live in confined and unsuitable flats due to financial problems. The exclusion is also strengthened by the state the buildings are in, as these are often in ruined conditions, and also by the acceptance of the status quo.

The living standards are, according to Burjanek ${ }^{23}$ in direct correlation with involuntary exclusion, and strengthen the cause for exclusion following the excluded group keeping to the behavioural patterns not accepted by the majority.

${ }^{22}$ Constant, Zimmermann, 2011, pp. 145 - 168.

${ }^{23}$ Burjanek 1997, pp.38-52. 
The physical conditions are manifested mainly by low hygiene standards and by the services provided, ${ }^{24}$ which is supported by the following statement:

"There's only one toilet at the floor, it doesn't take long for anybody to get there, even those with the older kid, you know I'm carrying the shopping bags, and his dad is standing next to him, and he's pissing down the staircase "( Jiřina -original resident 2013)

Apart from inner causes for exclusion and the strategies of the original residents, there are also outer agents contributing to exclusion, not negligible ones. Crucial seems to be the accumulation of residents on the basis of socio-economic status, and thus in turn the increase in the concentration of socially weak citizens at one place regardless on the ethnicity. A significant factor to be mentioned is strong reluctance of the real estate's owners to rent flats to the current residents, and last but least there is a pressure that has emerged on the basis of racism and the majority denying the Roma.

Even though the current residents show strategies leading to integration, the behaviour leading to exclusion as well as factors of exclusion are so strong, that some of the residents have been forced to move out of the area.

\section{The strategies and the goals of gentrifies}

The motivation of the gentrifies is common, the crucial role plays the low prices housing. As long as strategies and goals are concerned, the gentrifies can be divided into three groups: students, gentrifies - residents, gentrifies - entrepreneurs.

Gentrifiers - students- this group shows high flexibility and short term stay. This group is numerous, so it is not negligible; it is often a pioneer group of gentrifies.

Students are known for their alternative lifestyles and for being tolerant towards the neighbourhood, so they do not mind the neighbourhood being socially and ethnically variable. Students thus can revitalise the area, their influence is short term though. They do not stay there on long term basis, as they usually stay there during the college terms, and so they do not set their families in the area, which would be needed for ethnical coexistence.

The gentrifies residents are called residents who have bought flats in the area to live in, and who intend to stay there on long term basis. This is what Ms. Magdalena had to say on the motivation to come.

"We couldn't afford to buy the old flats... for us it is only a ferw minutes' walk to the city centre from here... the flat is good and it can be repaired, but as far as safety in the street is concerned, it is not more dangerous here than anywhere else. What we did not know though was that there were kids here hanging around and taking drugs." (Magdalena - gentrifies resident, 2013)

${ }^{24}$ Burjanek 1997, pp.38-52. 
This group can significantly help the original residents integrate in the generations to come. If these stay in the area and if they have families, it is likely that the original residents will take to them and integrate with the gentrifies over the time. The gentrifies often tend to move out of the area when they want to have children for security reasons as they fear exclusion related behaviour impacts. The gentrifies-residents contribute to exclusion only partly by taking advantage of services and goods that the socially weak people cannot afford.

The last group are gentrifies-entrepreneurs and the house owners whose businesses are related to real estates. One of the ways of making business with real estates in this area has been moving the socially weak tenants into flats that are in much worse conditions in order to be able to sell the flats; they have so far lived in, for market prices.

What also encourages exclusion is the fact that there are many pawn shops and gambling clubs in the area, both of which encourage the socially weak in economically unsound conduct.

Gentrifies-entrepreneurs are effectively an instrument of exclusion, and accelerate the gentrification process through forcing the original residents out of the area.

\section{The strategies and goals of the non-profit organisations}

The non-profit organisations' main goal is to help the original residents in coping with their problems. Their strategies are exclusively of integrative character, within the framework of which there are leisure activities, educational activities, field works and advisory activities.

NGOs focus mainly on coping with specific problems of the residents and put stress on an individual. Homogeneity of the target group, the NGOs are occupied with, is based on social and economic exclusion, for which reason the NGOs pursue breaking the barrier of exclusion and lowering the number of excluded persons in the area. The integrative strategies of the NGOs are based on an equal approach, promoting the acceptance of double identity and providing advisory services.

Another strategy of the NGOs is activities connected with the city and the city parts. They play role of a mediator with thy city officials dealing with the needs and demands of the original residents. They also cooperate on common projects with the municipal authorities. The NGOs are not only a council while planning projects, they also effectively apply projects.

There also some discrepancies too. The Integrated city development plan is criticised by the NGOs for forcing the original residents out of the area. According to the NGOs those who benefit from the European funds subsidies are in fact the gentrifies rather than the original residents.

What is apparent is that the ideas of the NGOs and the municipal authorities concerning the support of the current residents differ, and that there is mutual misunderstanding concerning the goal of the project. It shows that the strategies of the 
participants are different. The idea of municipal authorities is revitalization of the area, while NGOs solely focus on integrative activities. There is a match point of these strategies, what must be taken into account, though, is the fact that for the city the policy of integration is one of the main strategies, nonetheless it is not the sole goal.

\section{The strategies and the goals of the municipal authorities and the city parts Brno-centre and |Brno-north}

The goals of the city have been defined clearly, what is crucial is to put the area into a state comparable with the other city parts in terms of social conditions and housing. The key words being used are revitalization, city renewing, city regeneration, which are euphemisms for exclusion. These keywords do not point out social status though, which, on the contrary, the term gentrification the term gentrification does. ${ }^{25}$

The representative of the city part Brno-north had this to say on the plans with the area Cejl / Bratislavská

"The intention of Brno-north is to restore the original function of this area in the future, to make it a residential area in the vicinity of the city centre, so it wouldn't be excluded area any more". (Representative of the city district Brno-sever, 2013)

The same intention is defined in a handbook called Integrated plan of city development in problematic residential areas 2008-2015“ issued by the municipal authority "The goal of the integrated plan of city development is to improve the current status quo in the defined socially excluded area by improving the state the houses in the area. ${ }^{26}$

"The strategy to achieve improvement also includes, apart from modification of the public areas: complex package of field social and educational services being concurrently provided promoting the competences of the residents of the socially excluded area, which is to lead to improving the socio-economic standards and following to social mobility based on responsible and informed approach. ${ }^{27}$

Building social flats in the houses being reconstructed is another important factor of integration. Getting a social flat is not the option open for all of the socially weak residents. The applicants for a social flat must meet a number of criteria, with wages being one of the main criteria. This step is nonetheless way to cooperation between the city and the original residents and it is also a token of acceptance of the minority while deciding on the area development. ${ }^{28}$ The option of living in social flats opens the way to

${ }^{25}$ Lees, Slater, Wyly 2008.

${ }^{26}$ IPRM Handbook, 2012, Př́ručka Integrovanébo plánu mèsta Brna, 25.3.2019.

${ }^{27}$ IPRM Handbook, 2012, Přiručka Integrovaného plánu mèsta Brna, 25.3.2019.

${ }^{28}$ Regelmann 2009, pp. 175-198. 
staying for the original residents, who were indebted in the past, while those who refuse to pay the rent are forced out of the area.

Key point here is also the changed policy of the city that goes hand in hand with the Integrated plan of the city development. The value of the apartment houses has been stabilizing due to the revitalization of the houses that is in progress, which has led to privatisation of the apartment's houses being minimized. This strategy of the city has also slowed down the activities of the gentrifies-entrepreneurs, who have been trading with the flats.

While taking into account inclusive and exclusive aspects of the program of massive revitalisation in the area we have to acknowledge that this does not lead to improvement in life situation for a significant part of the residents but to further exclusion. The reconstruction of the apartment houses is often a pretext for evicting the tenants who have not been paying the rent for some time due to being indebted.

In the reconstructed houses there are social flats for the socially and indebted families though, and thus these are provided with quality housing. The reconstruction of the apartment flats is financed by the city, and it is not progressing as quickly as it is in case of private buildings.

\section{Summary of the findings and the main}

If we take into account the history of the excluded area Bratislavská - Cejl, we acknowledge that the current state is a creeping consequence of the post war events.

The genocide of the WW2 as well as forced relocation of citizens were significant impacts to the settlement structure in the area and led in turn to fluctuation of citizens in the area.

Slow decay of the houses along with low maintenance of the houses led to the area degradation. All of these factors have led to socially weak people cumulating in the area. The long undealt with situation has led to the area being socially excluded.

The current revitalisation is an attempt to restore life. There is a high chance of it succeeding; mistakes made in the past should be avoided though.

There has been a shift in the political plans concerning the area Bratislavská / Cejl, flats privatisation was preferred until 2008. With the possibility of financing the revitalization from the European union funds the city has come to prefer to keep the flats in its possession.

Milder attitudes toward socially weak residents go hand in hand with this political shift resulting in higher chance of them staying in the area. There is also the cooperation of the city with the NGOs on the integration process to be mentioned.

The research has led to conclusion that not only identity an economic factors, as assumed by Klaus Zimmermann, ${ }^{29}$ lead to successful integration, but the city policy is an important factor of integration too.

${ }^{29}$ Constant, Zimmermann, 2011, pp. 145-168. 
What is important in terms of understanding the gentrification process is the connection between the city institutions and the gentrifies, who help implement the current policy of the city part Brno-centre and Brno-north. Gentrifies can be seen as a homogenous group in terms of their interests which are relatively cheap purchase of real estates and low rents.

Gentrifies -students and gentrifies - resident colonise the area with the intension of a temporary stay or permanent stay, while they indirectly and accidentally take part in gentrification and support the city policy. The assumption that there are residents considering permanent stay has been verified during the empirical research, and so new generations of gentrifies can be expected to be born in the area, thus leading to integration of the original residents. ${ }^{30}$

Gentrifies - entrepreneurs form a group effectively gentrifying and activating the aim to exclude the original residents. Gentrifies - entrepreneurs are in terms of their interest in opposition to the pursued goals of the non-profit organisations

Another factor contributing to exclusion of the original residents is the excluded environment they live in, which motivates them to behaviour not accepted by the majority. The state of being indebted is one of the consequences of the behavioural patterns of the excluded residents, which in turn leads to enforcing the gentrifies - entrepreneurs. That leads to further exclusion of the residents of Bratislavská / Cejl.

The basic question whether there is room for the integration of the original residents has had positive answer in spite unfavourable conditions. There is a match point of the interests of non-profit organisations, municipal authorities and the gentrifies - residents, even though the only direct strategy is the one of non-profit organisations.

The change of the city strategy in 2008 along with cooperation with the non-profit organisations and permanent stay of the gentrifies - residents give chance to some of the original residents to stay. This possibility is open only to a small part of the overall number of the original residents, due to the general demand not to get indebted. The harsh conditions of gentrification will most likely force most of the original residents out of their home ground into less lucrative city parts or to rooming houses. Still there is a possibility of integration in the area, and part of the resident will probably take the opportunity. It is not, nonetheless, a massive trend but with the new city policy there has been significant progress in integration.

\section{Bibliography:}

Bittnerová D., Moravcová M. 2011, Integrace - identita [in:] Bittnerová B., Moravcová, M. (ed.) Etnické komunity, integrace, identita, FHS UK, Praha, pp. 9-15.

${ }^{30}$ Bittnerová, Moravcová 2011,pp. 9-15. 
Bonner A. 2006, Social Exclusion and the Way Out: An Individual and Community Response to Human Social Dysfunction, Wiley-Blackwell, London.

Burjanek A. 1997, Segregace, „Sociologický časopis“, Vol. 33 (1997), pp.38-52.

Constant A.F., Zimmermann K.F. 2011, Migration, Ethnicity and Economic Integration (December 2009) [in:] Jovanovic, M. N. (ed.), International Handbook on the Economics of Integration, Edward Elgar Publishing, Cheltenham, pp. 145-168.

Creswell J.W. 2007, Qualitative inquiry and research design: Choosing among qualitative approaches, Thousand Oaks, CA: Sage.

Dahrendorf R. 1988, The Modern Social Conflict: An Essay on the Politics of Liberty, George Weidenfeld and Nicolson, London.

Finney N., Simpson L. 2009, Sleepwalking to Segregation?: Challenging Myths About Race and Migration, The Policy Press, London.

Glass R. 1964, London: aspects of change, „Centre for Urban Studies“ No. 3, MacGibbon \& Kee, London, pp 342.

Hamnett C. 2003, Gentrification and the Middle-class Remaking of Inner London, 1961-2001, „Urban Studies“Vol. 40, No. 12, pp. 2401-2426.

Holzner B., 1967, The Concept "Integration" in Sociological Theory, "The Sociological Quarterly", Vol. 8, pp. 51-62.

Lees L., 2008, Gentrification and social mixing: towards an inclusive urban renaissance?, „Urban Studies“, Vol. 45, No.12, pp. 2449-2470.

Lees L.; Slater, T.; Wyly E. 2008, Gentrification, Routledge, New York.

Ley D. 1986, Alternative explanations for inner-city gentrification, „Annals of the Association of American Geographers“Vol. 76, pp. 521-535.

Maloutas T. 2011, Contextual Diversity in Gentrification Research, „Critical Sociology“, Vol. 38, No. 1, pp. 33-48.

Marcuse P. 1997, The Ghetto of Exclusion and the Fortified Enclave: New Patterns in the United States, „American Behavioral Scientist“, special issue, „The New Spatial Order of Cities“, Vol. 41, No.3, pp. 311-326.

Ogbu J. U. 2003, Black American Students in an Affluent Suburb. A Study Academic Disengagement, Mahwah: LEA.

Pospíšilová J., Brožovičová K. 2015, Dělnický di̊m a proměny sociálně vyloučené oblasti. Př́padová studie lokality Brno-Cejl. „Journal of Urban Ethnology“, Vol. 13, p. 157-177.

Pospíšilová J., Poláková J., Brožovičová K. 2015, National Minorities in Brno. The Cultural Heritage of Roma in Excluded Locations. „Journal of Ethnology“, Vol 25, No. 5, p. 18-34.

Regelmann A. 2009, Political Community, Political Institutions and Minority Politics in Slovakia, 1998-2006 [in:] Agarin, T and Brosig, M (ed.) Minority Integration in Central Eastern Europe: Between Ethnic Diversity and Equality, Rodopi, Amsterdam/New York, pp. 175-198.

Silver H., Miller, S.M. 2003, Social Exclusion: The European Approach to Social Disadvantage. „Indicators“Vol.2, No.2, pp. 6-15. 
Sirovátka T. 2007, Dynamika soudobébo trhu práce: Flexibilita, segmentace a inkluze [in:] Mareš, P., Hofírek, O. (ed.) Sociálni reprodukce a integrace: Ideály a meze. Masarykova univerzita, Mezinárodní politologický ústav, Brno, pp. 85-99.

Smith N.1996, The Nerw Urban Frontier: Gentrification and the Revanchist City, Rutledge, London. Smith N. 2003, Gentrification and the rent gap, „Annals of the Association of American Geographers", Vol. 77, pp. 462-465.

Townsend P. 1979, Poverty in the United Kingdom: a survey of household resources and standards of living, Penguin Books, Harmondsworth.

Vleminckx K., Berghman J.2001, Social Exclusion and the Welfare State: An Overview of Conceptual Issues and Policy Implications [in:] Mayes, D, Berghman, J. a Salais, R. Social Exclusion and European Policy, Edward Elgar, Northampton, MA, pp. 27-46.

\section{Internet Sources:}

SLDB 2011 - vybrané výsledky podle městských částí Brna. 2011. Český statistický úřad, https:// www.czso.cz/csu/xb/sldb_2011_vybrane_vysledky_podle_mestskych_casti_brna, 12.03.2019.

Official website of the Institut Terezínské iniciativy, http://www.holocaust.cz/databaze-obeti/, 19.03.2019.

IPRM Handbook, 2012, Př́ručka Integrovanébo plánu města Brna. http://www.mmr.cz/getmedia/030d19a9-8b5a-4393-b7fd13b6276ced30/Kalaskova.pdf?ext=.pdf, 25.3.2019. 